\title{
Impeachment de Dilma Rousseff: análise das estratégias argumentativas de Veja e CartaCapital após a votação na Câmara dos Deputados $^{1}$
}

\section{Rejane de Oliveira Pozobon}

Doutora; Universidade Federal de Santa Maria, Santa Maria, RS, Brasil

rejane.op@terra.com.br

\section{Carolina Siqueira de David}

Mestranda; Universidade Federal de Santa Maria, Santa Maria, RS, Brasil

caroldedavid@hotmail.com

\section{Resumo}

Este artigo analisa as matérias "Folga de 25 votos", da revista Veja, e "Sorriso da Mona Lisa", da revista CartaCapital, ambas referentes à votação do processo de impeachment de Dilma Rousseff na Câmara dos Deputados. Como referencial teórico, nos apoiamos em autores como Foucault, Bourdieu e Charaudeau que abordam o discurso e as relações de poder em sociedade. Para uma aproximação com nossos objetos, nos embasamos, principalmente, em Charaudeau que disserta sobre o discurso das mídias. A metodologia é baseada nas quatro estratégias argumentativas expostas por Breton: autoridade, enquadramento, comunidade e analogia. Como conclusão, observamos que as revistas convergem quando expõem um perfil negativo de Eduardo Cunha e impopularidade de Michel Temer, porém, diferem sobre outros participantes do processo como Dilma Rousseff e Lula.

\section{Palavras-chave}

Discurso das mídias. Impeachment. Dilma Rousseff. Veja. CartaCapital.

\footnotetext{
${ }^{1}$ As questões abordadas neste artigo são aprofundadas em uma pesquisa de dissertação que analisa as três etapas do processo de impeachment de Dilma Rousseff.
} 


\section{Introdução}

O processo de impeachment de Dilma Rousseff teve sua votação na Câmara dos Deputados no dia 17 de abril de 2016. Por maioria de votos, o processo seguiu para a primeira votação no Senado Federal, no dia 12 de maio do mesmo ano, onde foi decidido pelo afastamento de 180 dias da então presidente Dilma Rousseff. No dia 31 de agosto de 2016, Dilma Rousseff foi impedida de continuar seu governo.

Sabendo que as mídias têm um papel importante na informação de acontecimentos, atuando não somente como divulgadora de informação, mas construindo juízos de valor e julgamentos para os fatos, se encontra a importância dessa análise. Nesse sentido, optamos por analisar duas das maiores revistas brasileiras em circulação que são Veja e CartaCapital. A escolha das revistas se dá, especificamente, porque ambas têm pensamentos distintos sobre várias temáticas, em especial, a política. Desse modo, acreditamos que esta pesquisa pode contribuir para compreender como essas duas mídias impressas, a partir de suas estratégias argumentativas, se referiram à etapa do impeachment que compreende a votação na Câmara dos Deputados.

Para atingirmos nosso objetivo, nos apoiamos em autores (FOUCAULT, 1999; BOURDIEU, 1994, 1998, 2012) que dissertam sobre o poder dos discursos em sociedade e o quanto esse poder é, na verdade, próprio das instituições e não dos indivíduos. Ainda, abordamos o que é o poder, a partir de Charaudeau (2016), quando este o acredita submerso em questões de autoridade, legitimidade e potência. Em sequência, para uma aproximação com nossos objetos, nos baseamos, principalmente, em Charaudeau (2015) para dissertar sobre o poder das mídias a partir do seu discurso de informação. Logo após, apresentamos nossa análise referenciada, metodologicamente, nas estratégias argumentativas de autoridade, comunidade, enquadramento e analogia de Breton (2012), e por fim, nossas conclusões.

\section{Discurso e poder}

Nas primeiras páginas da obra A ordem do discurso de Foucault (1999) - transcrita da sua aula inaugural no Collegè de France, em 1970 - podemos observar a seguinte frase: “E a instituição responde: Você não tem porque temer começar; estamos todos aí para lhe mostrar que o discurso está na ordem das leis; que há muito tempo se cuida de sua aparição 
[...] e que, se lhe ocorre ter algum poder, é de nós, só de nós, que ele lhe advém." (FOUCAULT, 1999, p. 7).

Nesse sentido, essa ideia, que é a instituição que concede o poder ao indivíduo, é a que permeia todo sua obra.

Para Foucault (1999), as instituições detêm discursos prontos os quais os indivíduos se apropriam. Ou seja, os discursos de certas instituições já estariam circulando na sociedade há muito tempo e, seriam, então, pré-existentes aos indivíduos. Desse modo, é justamente esse controle do discurso por parte de instituições que o poder se dá pela instituição que se fala e não por quem se fala: "[...] em toda a sociedade a produção do discurso é ao mesmo tempo controlada, selecionada, organizada e redistribuída por certo número de procedimentos que têm por função conjurar seus poderes e perigos [...]" (FOUCAULT, 1999, p. 9).0 discurso de uma instituição, propagado por uma pessoa que pertence a esta, qualifica essa pessoa como detentora de poder, mas, da mesma forma, esse poder nunca é pessoal e, sim, qualificado pela instituição. 0 que permite que uma pessoa possa propagar tal discurso através de uma instituição é, segundo Foucault (1999), o ritual. É o ritual que determina quais os comportamentos, gestos, enunciados que são permitidos por cada instituição, portanto, são papéis preestabelecidos. Nesse sentido, para Foucault (1999), o discurso é um jogo de escritura, leitura e troca, permeado por signos. Além disso, o discurso não é só a tradução das lutas e dos sistemas de dominação, mas aquilo que se luta para conquistar e se deseja ter.

Bourdieu (1998) compartilha desta ideia quando afirma que o poder não está nas palavras, nem no discurso, mas sim na pessoa social que pertence a alguma instituição: "O poder das palavras é apenas o poder delegado do porta-voz cujas palavras [...] constituem no máximo um testemunho [...] da garantia de delegação que ele está investido" (BOURDIEU, 1998, p. 87). Assim, para o autor, a autoridade presente na linguagem vem do exterior das palavras, ou seja, da legitimidade das pessoas que as pronunciam. Legitimidade essa que pode ser encontrada, segundo o autor, nas "rotinizações", "estereotipagem" e "neutralização". O processo no qual o porta-voz de uma instituição se reveste de legitimidade para falar sobre algo, é denominado cetro: "O porta-voz é um impostor provido de cetro (skeptron)." (BOURDIEU, 1998, p. 89). Além do mais, o porta-voz só consegue agir sobre os outros, porque é depositado nele o capital simbólico da instituição pela qual ele se pronuncia. 
É por isso que, de acordo com o autor, quando alguém que não é revestido de autoridade profere algo, o auditório não reconhece a sua autoridade e o processo enunciativo falha. Esse processo enunciativo compreenderia, justamente, a relação entre "[...] propriedades do discurso, as propriedades daquele que o pronuncia e as propriedades da instituição que o autoriza a pronunciá-lo." (BOURDIEU, 1998, p. 89). Isto, em parte, tem relação com o que Foucault (1999) coloca como interdição dos discursos, pois, para ele: "Sabe-se bem que não se tem o direito de dizer tudo, que não se pode falar de tudo em qualquer circunstância, que qualquer um, enfim, não pode falar de qualquer coisa." (FOUCAULT, 1999, p. 9).

Bourdieu (1998) atenta para as especificidades do discurso de autoridade (os sermões, por exemplo). Para o autor, esse tipo de discurso encerra nele mesmo um poder que é pertencente às condições institucionais de sua produção e recepção. Nesse sentido, o poder do discurso de autoridade, para o autor, não viria da pronúncia rebuscada ou da sua boa articulação, ou seja, das propriedades do próprio discurso, viria, justamente, do seu lugar de produção e reprodução social. Segundo ele, esse tipo de discurso não precisa ser compreendido, mas reconhecido e, ainda, proferido para um auditório legítimo:

A linguagem de autoridade governa sob a condição de contar com a colaboração daqueles a quem governa, ou seja, graças à assistência dos mecanismos sociais capazes de produzir tal cumplicidade, fundada por sua vez no desconhecimento, que constitui o princípio de toda e qualquer autoridade. (BOURDIEU, 1998, p. 91).

É nesse sentido que, para Bourdieu (1994), a linguagem não é somente uma função de comunicação, ela é estratégica, praticada em uma situação que declara sua competência prática. Dessa forma, de acordo com o autor, a estrutura linguística é reflexo das relações de força entre grupos, isto é, a linguagem configura-se como um instrumento de poder. Ela é um instrumento de poder porque, para Bourdieu (1994), não se busca somente ser compreendido, mas obedecido e respeitado. É isso que o autor coloca como a capacidade do indivíduo "impor a recepção", a capacidade do "se fazer escutar". Aqui, mais uma vez, Bourdieu (1994) se aproxima de Foucault (1999) quando este último apresenta a interdição, pois para Bourdieu (1994, p. 161): “Não falamos a qualquer um; qualquer um não 'toma' a palavra. 0 discurso supõe um emissor legítimo dirigindo-se a um destinatário legítimo, reconhecido e reconhecedor." 
Por conseguinte, Bourdieu (1994) dispõe o seguinte triângulo que faz parte do discurso legítimo: locutor legítimo, em uma situação legítima, para um público legítimo. Ou seja, a língua nunca é apenas gramaticalidade, ela é sempre permeada pelas suas condições de produção, pela posição social assumida pelo locutor e pelas relações de poder.

\section{As especificidades do poder}

Para Bourdieu (2012), o poder é simbólico e é conceituado como o poder invisível de imposição de normas de ver o mundo, o poder da construção da realidade. Não obstante, esse poder só pode ser exercido através da cumplicidade "[...] daqueles que não querem saber que lhe estão sujeitos ou mesmo que o exercem." (BOURDIEU, 2012, p. 8).

Ainda para o autor, o poder simbólico age a partir de estruturas estruturantes que são os sistemas simbólicos. A língua, ciência, arte e religião são sistemas simbólicos de nossa sociedade, sistemas esses que servem de instrumento para o conhecimento, organização e construção do mundo: Nesse sentido, os símbolos, segundo o autor, permitem o consenso e a reprodução social, pois são instrumentos de "integração social".

Os símbolos, na perspectiva de Bourdieu (2012), são, além de tudo, instrumentos de dominação porque estão envoltos por ideologias propagadas pelos grupos dominantes, que tentam fazer com que suas vontades sejam universais. É por isso que, de acordo com o autor, o campo da produção simbólica é permeado por lutas simbólicas de classes, pois as diferentes classes "[...] estão envolvidas numa luta propriamente simbólica para imporem a definição do mundo social mais conforme seus interesses." (BOURDIEU, 2012, p. 11).

É justamente por esses sistemas simbólicos serem estruturados que eles não são reconhecíveis. Nesse caso, o que concede uma aura "mágica" ao poder simbólico é que sua efetividade se dá por agir diretamente nas relações de força. Segundo Bourdieu (2012), o poder simbólico se iguala, muitas vezes, ao poder da força física, pois ele é imbuído de reconhecimento. Isto é, o poder simbólico não está nas coisas, mas na relação aceita entre dominante e dominado.

O que faz o poder das palavras e das palavras de ordem, poder de manter a ordem ou subverter é a crença na legitimidade das palavras e daquele que as pronuncia, crença cuja produção não é da competência das palavras. [...] 0 poder simbólico, poder subordinado, é uma forma transformada [...] das outras formas de poder. (BOURDIEU, 2012, p. 15). 
Como já expomos, pelas palavras de Bourdieu (1994, 1998, 2012), o poder é relacionado à autoridade e à legitimidade. Cabe a aproximação com Charaudeau (2016), quando este afirma que o poder é uma questão de autoridade, legitimidade e potência.

Para Charaudeau (2016), o poder é a capacidade de agir sobre o outro, ou seja, de submeter o outro. Ele é uma relação coercitiva e de alteridade entre dominante e dominado que precisa ser justificada e, de fato, é justamente pelas questões de autoridade, legitimidade e potência. Segundo o autor, a primeira questão é o que concede o reconhecimento de digno agir; a segunda é o que faz se ter o direito de agir e a última concerne os meios de agir.

A autoridade é, então, relacionada ao âmbito do saber-fazer, é o que dá crédito a alguém para fazer algo, ser reconhecido que se sabe fazer algo bem. Além disso, a autoridade não é dada, mas sim adquirida, conquistada pelo ponto de vista dos outros. Ainda, para o autor: "Pode-se ser legitimado na posição de [...] chefe de Estado, de diretor de um serviço e não ter o crédito necessário para exercer seu poder." (CHARAUDEAU, 2016, p. 15).

A legitimidade também concerne ser reconhecido pelo corpo social, mas, diferente da autoridade, concerne o direito de agir por uma finalidade aceita. É uma posição atribuída pela organização social, que envolve uma crença coletiva, é o que "[...] permite àquele que quer exercer um poder fazê-lo de acordo com uma posição atribuída por uma fonte exterior, mas que se incorpora a ele e é reconhecida por todos." (CHARAUDEAU, 2016, p. 15).

A potência é o conjunto dos meios e da força para que se possa agir sobre o outro, um exemplo prático pode ser a atribuição de nota, por um professor, pelo regulamento escolar. Ainda, a sanção pode ser tanto positiva quanto negativa. Nesse sentido, a potência é o ato de assegurar a obediência do outro. Assim como Charaudeau (2016), Stoppino (1998) afirma que o poder potencial é exercido por meio de recursos, exemplos desses recursos seriam a riqueza, a popularidade, a amizade, a informação.

Essas três questões, segundo o autor, interagem entre si. A potência, por exemplo, pode aumentar a legitimidade ou, ainda, dar crédito a ela, o que reforça a autoridade. Para o autor, “[...] o poder, para se exercer, necessita de uma legitimidade que sempre é atribuída de uma autoridade que se constrói para obter crédito e de potência como meio de agir." (CHARAUDEAU, 2016, p. 18). Em suma, ainda nas palavras do autor: "A legitimidade fundamenta o poder, e a potência lhe dá força." (CHARAUDEAU, 2016, p. 18).

A definição de poder de Charaudeau (2016) encontra a de Stoppino (1998) quando este último afirma que o poder é a capacidade de agir, e o mesmo poder, entendido num âmbito social, é a capacidade de agir sobre o outro: "Poder do homem sobre o homem. 0 
homem é não só sujeito, mas também o objeto do Poder social." (STOPPINO, 1998, p. 943). É nesta perspectiva que Stoppino (1998) afirma que não há poder se não existe um indivíduo que o detenha e o que seja induzido pelo poder. 0 autor ainda alega que o poder não está nas coisas, visto que é possível oferecer dinheiro por um desejo e a pessoa não aceitar. Nesse sentido, o poder está na relação entre pessoas, em relação a um outro, a alteridade colocada por Charaudeau (2016). Outra questão colocada por Stoppino (1998) é sobre a imagem do poder, isto é, a percepção social de sua existência.

A imagem que um indivíduo ou um grupo faz da distribuição do Poder, no âmbito social a que pertence, contribui para determinar o seu comportamento, em relação ao Poder. Neste sentido, a reputação do Poder constitui um possível recurso do Poder efetivo. (STOPPINO, 1998, p. 937938).

Podemos relacionar essas percepções com o que Foucault (1999) coloca como os rituais pertencentes a cada campo, ou seja, padrões de conduta que são exteriorizados por meios de gestos, comportamentos e discursos pré-estabelecidos. Stoppino (1998) ainda fala que o poder se trata de relação triádica: a pessoa que detém o poder; a pessoa na qual se exerce o poder e a esfera de atividade do poder. Com isso, o autor quer dizer que os indivíduos estão sujeitos a vários tipos de poder, de diversos campos: o do médico, a partir do discurso da saúde; do professor, a partir do discurso do saber, por exemplo. Acrescentamos, em decorrência dos objetos deste trabalho, o poder do discurso das mídias, aquelas que detêm o discurso da informação.

\section{0 discurso de informação das mídias}

De acordo com Foucault (1999), no século XVII, se experimentou uma nova vontade de verdade, não mais ligada ao exercício do poder, mas às instituições. Essa base institucional legitimava o discurso da verdade por meio de sistemas de livros, bibliotecas, laboratórios, isto é, uma série de práticas estabelecidas. Dessa maneira, para Foucault (1999), esse tipo de discurso exercia, e ainda exerce, pressões sobre outros discursos para que eles se moldem conforme esse discurso verdadeiro.

O autor apresenta o exemplo de Gregor Mendel, famoso botânico, que teve seus estudos rejeitados por aplicar novas e desconhecidas técnicas, ou seja, fora do "molde" do 
discurso verdadeiro para a biologia naquela época. "Mendel dizia a verdade, mas não estava "no verdadeiro" do discurso biológico de sua época: não era segundo tais regras que se constituíam objetos e conceitos biológicos [...]" (FOUCAULT, 1999, p. 35).

Para Charaudeau (2015), o discurso informativo se aproxima de um discurso entendido como "didático". Se o interesse do jornalismo, como empresa, é atingir a maior quantidade de pessoas possíveis para obter lucro, ele age, segundo o autor, por meio de uma vulgarização. A vulgarização é o ato de explicar um fato de maneira acessível a pessoas que tem diferentes níveis de entendimento, é por isso que para Charaudeau (2015) toda vulgarização implica uma deformação do fato.

Nesse sentido, se a mídia se propõe a escrever um discurso técnico ou especializado, ou seja, de acordo com as especificidades do campo em que o discurso primário foi produzido, seu discurso seria pouco comunicável, o que implicaria uma baixa captação. Para o autor, "[...] as mídias trapaceiam cada vez que uma explicação é apresentada como a decodificação simplificada de uma verdade oculta, como acessível a todos e a mesma para todos graças ao efeito mágico da vulgarização." (CHARAUDEAU, 2015, p. 63). De acordo com Charaudeau (2015), essa vulgarização é, ainda, "dramatizada".

A dramatização é mais uma estratégia das mídias para captação de público. Conforme o autor, as mídias tendem a mobilizar o público ao focar em sua afetividade, procurando, assim, desencadear uma "paixão" pela informação. Para mobilizar esses sentimentos e emoções, as mídias, para Charaudeau (2015), se baseiam nos imaginários sociais e crenças socioculturais presentes em cada comunidade. Para interpelar esse "fazer sentir" do público, as mídias produzem, então, encenações discursivas, marcadas, muitas vezes, pela espetacularização da informação.

Esse "fazer sentir", que faz parte, segundo o autor, de uma visada de captação do contrato de comunicação, vai de encontro à outra visada importante do mesmo contrato: a credibilidade, que alude ao "fazer saber", ou seja, ao sério, racional, credível. Sobre esse ponto de vista, o autor sustenta que o contrato de informação midiático é marcado pela contradição.

Na tensão entre os polos de credibilidade e de captação, quanto mais as mídias tendem para o primeiro, cujas exigências são as da austeridade racionalizante, menos tocam o grande público; quanto mais tendem para a captação, cujas exigências são da imaginação dramatizante, menos credíveis serão. (CHARAUDEAU, 2015, p. 93). 
Essa contradição do contrato de comunicação é também exposta em um discurso didático, que já comentamos antes. De acordo com o autor, as mídias não poderiam ser tão didáticas como se é no contexto acadêmico e no científico justamente porque as exigências de provas e verificações da didaticidade são incompatíveis com a visada de captação.

Charaudeau (2015) expõe outras duas razões para que não se confunda o discurso didático com o informativo: o primeiro (discurso didático) visa um alvo determinado e um saber já estabelecido no lugar de verdade; já o segundo (discurso informativo) visa sempre o maior alcance da informação e procura descobrir fatos. Há, segundo o autor, três questões que se apresentam no momento em que o discurso didático e o informativo se encontram: deformação, amálgama e psicologização.

A deformação é entendida pelo autor como aquilo que devido às interpretações pessoais do jornalista, da política da empresa e da interpretação feita pelo próprio público tende a produção de um conflito de entendimento. 0 ato de interpretar um discurso jornalístico depende do grau de entendimento também do público e é isso que faz com que algumas pessoas questionem determinados textos informativos. Para o autor, uma informação coloca em jogo o implícito e o explicito, e sua decodificação depende de quem lê.

O amálgama é, conforme Charaudeau (2015), um "efeito discursivo" que leva em conta a simplificação e a dramatização. 0 amálgama é como uma etiqueta que generaliza eventos que são singulares, mas que tem alguma similaridade entre si. Funciona como um estereótipo de rápida decodificação por produzir analogias e interferir no imaginário social e cultural do público. 0 autor cita o exemplo dos casos de corrupção, que por alguma similaridade, são etiquetados em conjunto, produzindo efeitos de acumulação e causalidade.

A psicologização, para o autor, é a que cria a "paranoia polêmica" na sociedade. Ao explicar os fatos aderindo a psicologização, as mídias criam uma espécie de "terceiro todo poderoso" ao apresentar os atores dos fatos como calculistas e planejadores de vítimas. Para o autor, isso acontece porque as mídias fazem correlações supondo intenções, logo, essa paranoia é que produz polêmicas sociais de conspiração por parte de pessoas ou grupos, ou de apresentação de culpados.

Delineadas algumas características do discurso informativo, passamos, agora, à apresentação dos procedimentos metodológicos deste trabalho e, logo após, introduzimos nossa análise, baseada na teoria da argumentação. 


\section{Análise}

Muito do que se conhece sobre a argumentação deve-se a outros campos do conhecimento - como a Retórica e o Direito - que não a Comunicação. Breton (1999) é o autor que aproxima a argumentação das Ciências da Comunicação. Inspirado em Perelman e Olbrechts-Tyteca, responsáveis pela obra Tratado da argumentação: A nova retórica e em Oswald Ducrot e Oliver Reboul, Breton (1999), na sua obra A argumentação na comunicação, introduz sua visão sobre a argumentação como uma situação de comunicação.

Na perspectiva dessa aproximação, o autor afirma que o clássico esquema linear: emissor, mensagem e receptor, não pode ser aplicado às situações argumentativas. Dessa forma, o autor propõe um "triângulo argumentativo", constituído pelos seguintes níveis: a opinião do orador, que é do domínio do verossímil, aquilo que se acredita antes de ser colocado em forma de argumento; o orador, que é aquele que argumenta para um auditório afim de que o mesmo compartilhe de sua opinião; o argumento, que é a opinião "colocada para convencer", em um raciocínio argumentativo; o auditório, o público ou o conjunto de público que se quer convencer e, por fim, o contexto de recepção, que são as opiniões, valores e julgamentos presentes na consciência do próprio auditório, que pode facilitar ou dificultar a adesão à opinião do orador.

Ainda para o Breton (1999), o objeto da argumentação é a "[...] transformação de uma opinião em argumento em função de um auditório particular." (BRETON, 1999, p. 32). Nesse sentido, ele expõe que se formos tratar da prevenção às drogas com um auditório constituído por professores e por policiais, usamos argumentos diferentes. Argumentaríamos, para os primeiros, que "a prevenção é um ato pedagógico" e, para os segundos, que "a prevenção diminui os delitos". Por conseguinte, a opinião pode ser uma só, mas é colocada em forma de argumento sempre em relação a quem se vai argumentar, ou seja, segundo Breton (1999), argumentar é ressaltar determinados aspectos de uma opinião que a tornarão aceitável para aquele público.

Aproximando-nos dos nossos objetos de análise, podemos afirmar que as mídias sempre atuam em função do seu auditório, ou seja, de seu público leitor. Elas procuram, como já foi dito no item anterior, através do contrato de comunicação, mobilizar sentimentos e garantir o alcance de sua informação. As mídias apresentam, em seus textos comunicativos, diversos argumentos que induzem a uma aceitação da opinião exposta por elas. É nesse sentido, de analisar quais estratégias argumentativas estão presentes nos 
textos midiáticos, que nosso corpus é constituído por duas matérias pertencentes à mídia imprensa brasileira: revista Veja e revista CartaCapital.

Devido à extensão deste trabalho, optamos por analisar uma matéria em cada revista. Sendo assim, em Veja, analisamos a de nome "Folga de 25 votos" (páginas 8 a 13, JUNIOR et al., 2016) e, em CartaCapital, a de nome "O sorriso da Mona Lisa” (páginas 18 a 23, BARROCAL, 2016). Ambas edições são referentes à votação do processo de impeachment de Dilma Rousseff, que ocorreu na Câmara dos Deputados no dia 17 de abril de 2016.

Figura 1 - Capa Veja, edição extra 2474, ano 49, de 21 abr. 2016

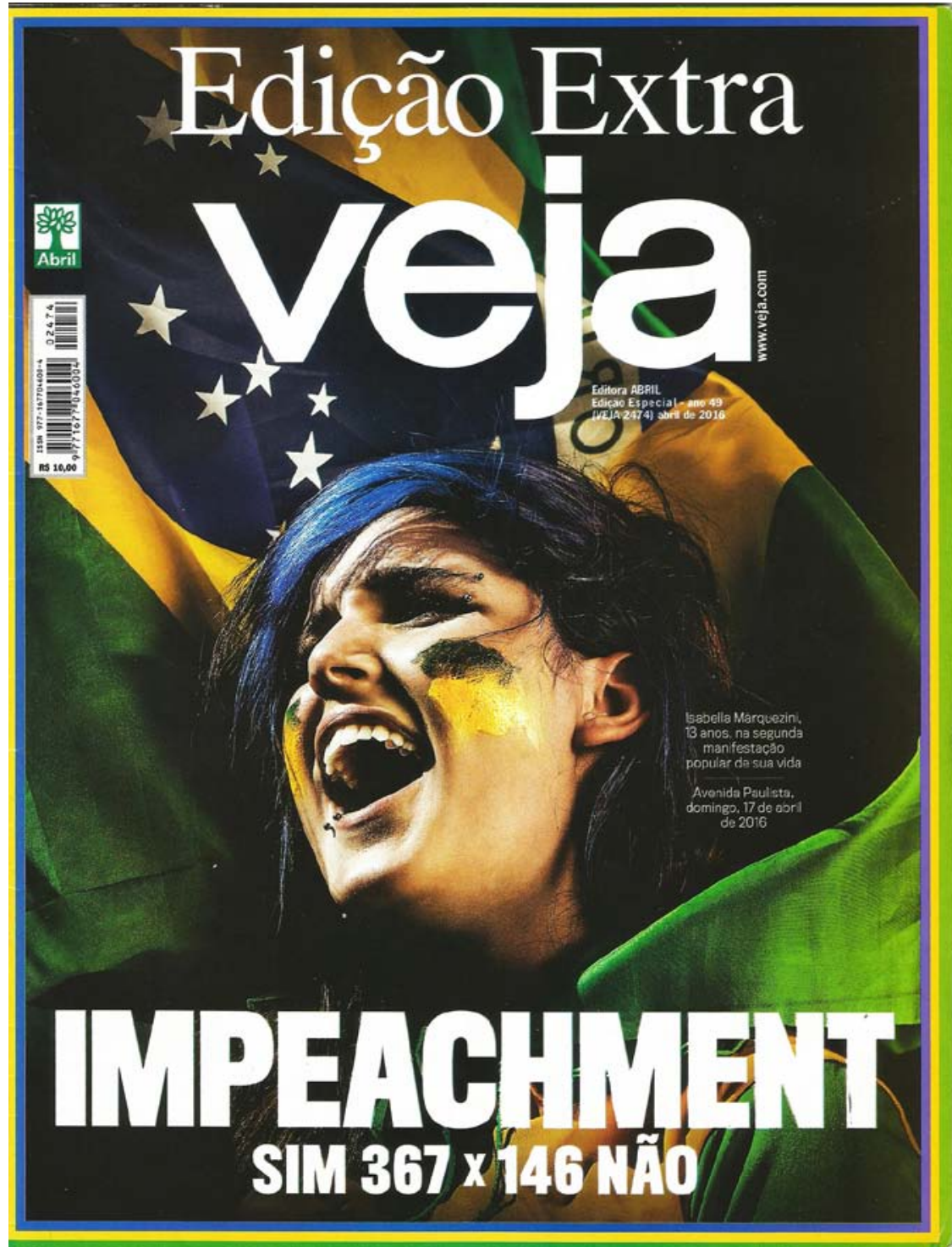

Fonte: Veja (2016) 
Figura 2 - Capa Carta Capital, edição 989, ano 22, 27 abr. 2016

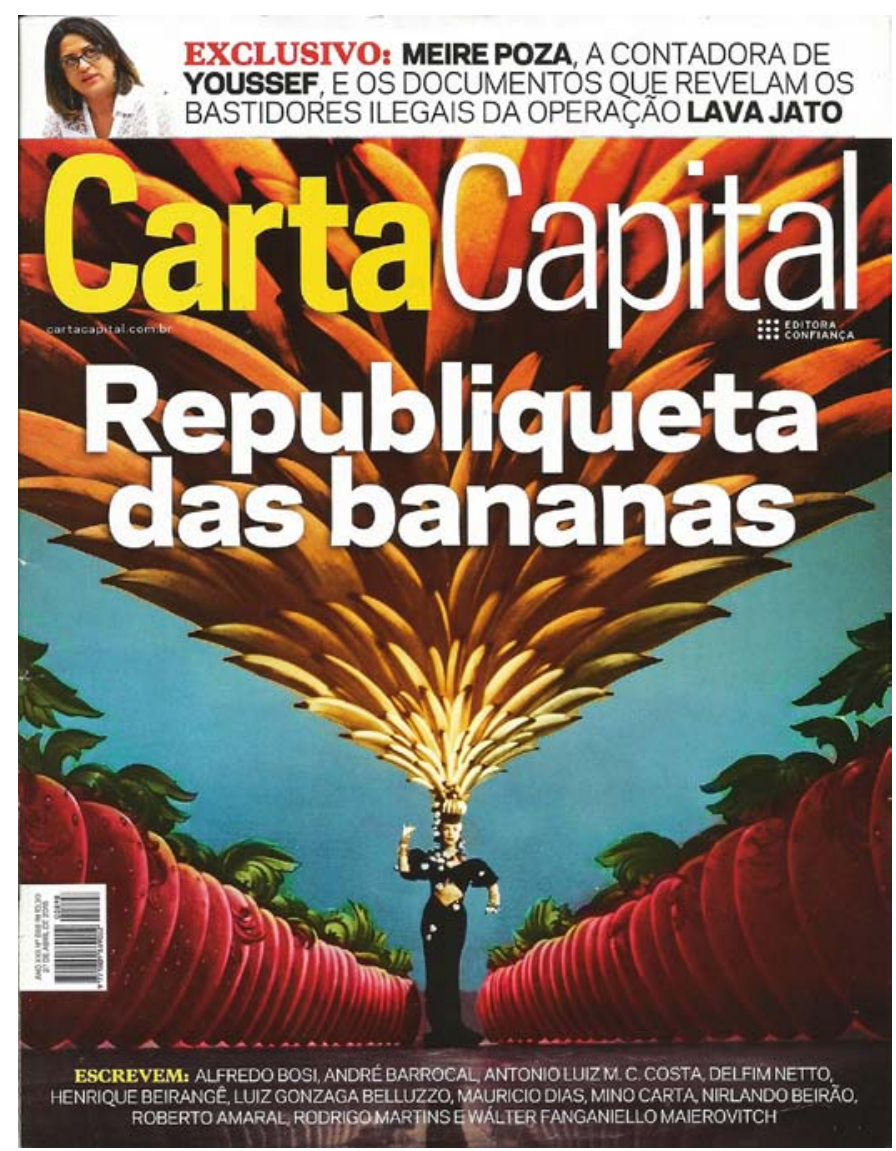

Fonte: Carta Capital (2016).

Dessa forma, para a aplicação metodológica, nos baseamos no texto de Breton (2012), o qual ele reduz a grande taxionomia de argumentos em quatro famílias: autoridade, que mobiliza uma autoridade aceita pelo público seja por sua competência, experiência ou testemunho; comunidade, que interpela os pressupostos comuns, crenças e valores de uma sociedade; enquadramento, que "enquadra" o fato de uma certa maneira, uma vez que pode limitar ou ampliar certos aspectos e, por fim, analogia que manifesta por meio de metáfora ou comparação.

Sobre os argumentos de autoridade e comunidade, podemos retomar alguns aspectos que já foram comentados no primeiro item deste trabalho. Bourdieu (2012) atenta para o discurso de autoridade que é fechado em si mesmo, ou seja, é um discurso de poder, pois é cerceado pelas suas condições de produção. Já o de comunidade é congruente com o que Charaudeau (2015) expõe como os textos que trazem questões sobre o amálgama, que criam estereótipos e apelam para as crenças e valores compartilhados em sociedade, ou seja, apelam para o "fazer-sentir". 
Assim, nosso procedimento metodológico se configura através de três eixos: no primeiro estabelecemos seis atores políticos que, devido a análises anteriores, consideramos pertinentes: Dilma Rousseff, Lula, Partido dos Trabalhadores (PT), Michel Temer, Eduardo Cunha e o próprio Impeachment.

No segundo eixo, apresentamos quais estratégias argumentativas vamos analisar e, no último eixo, estabelecemos, a partir de frases agrupadas em categorizações, quais as finalidades das estratégias argumentativas que falam sobre esses atores políticos.

Figura 3 - Eixo 1: Atores políticos

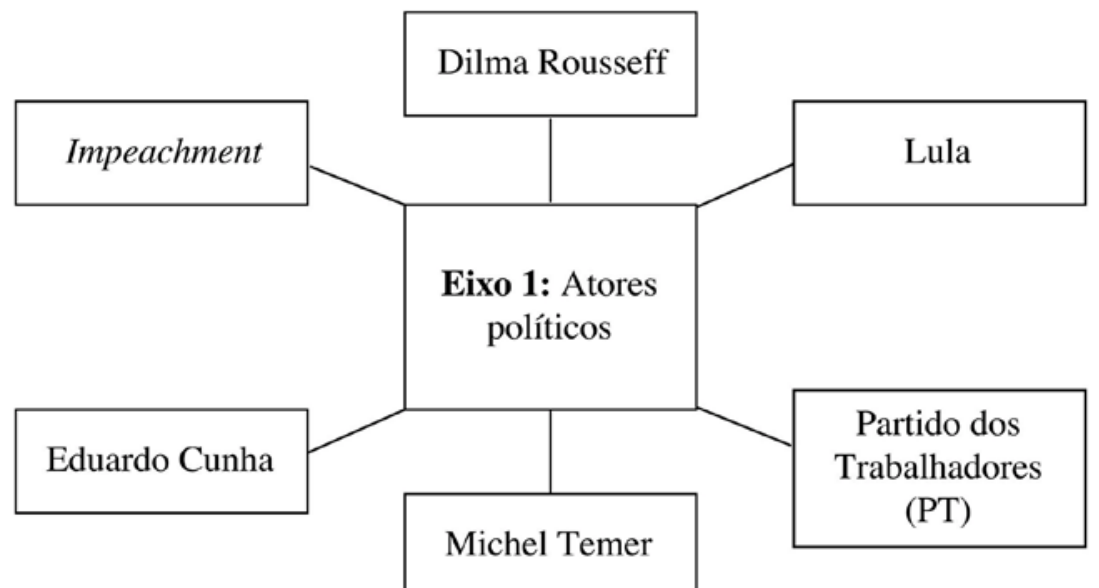

Fonte: Elaborado pelas autoras.

Figura 4 - Eixo 2: Estratégias argumentativas

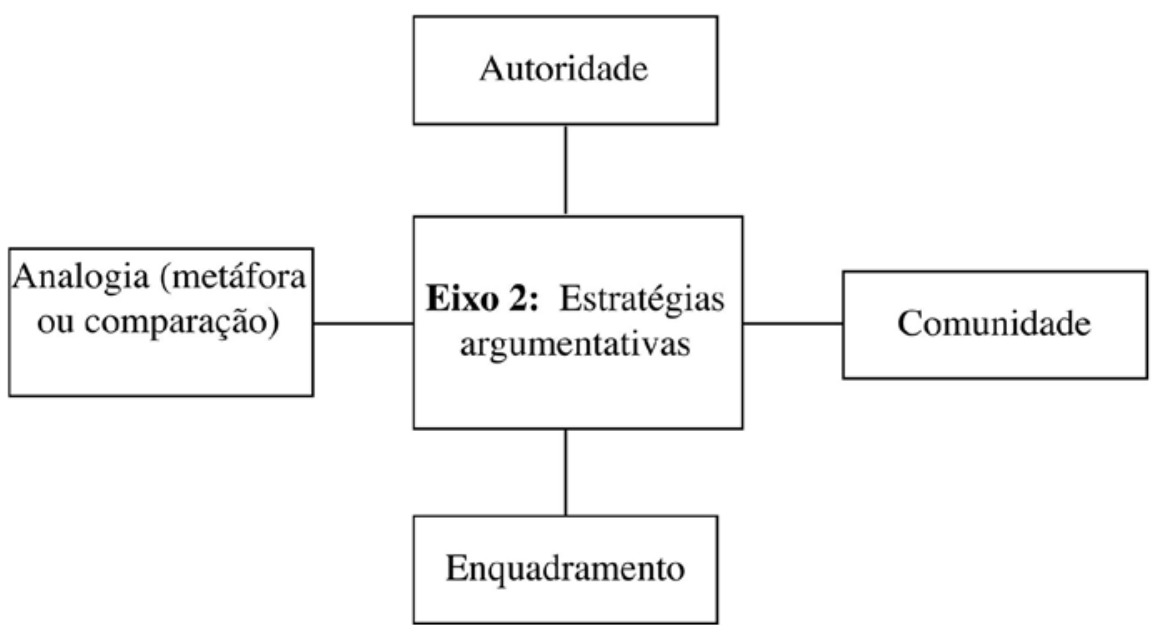

Fonte: Elaborado pelas autoras. 
Figura 5 - Eixo 3: Finalidade das estratégias argumentativas

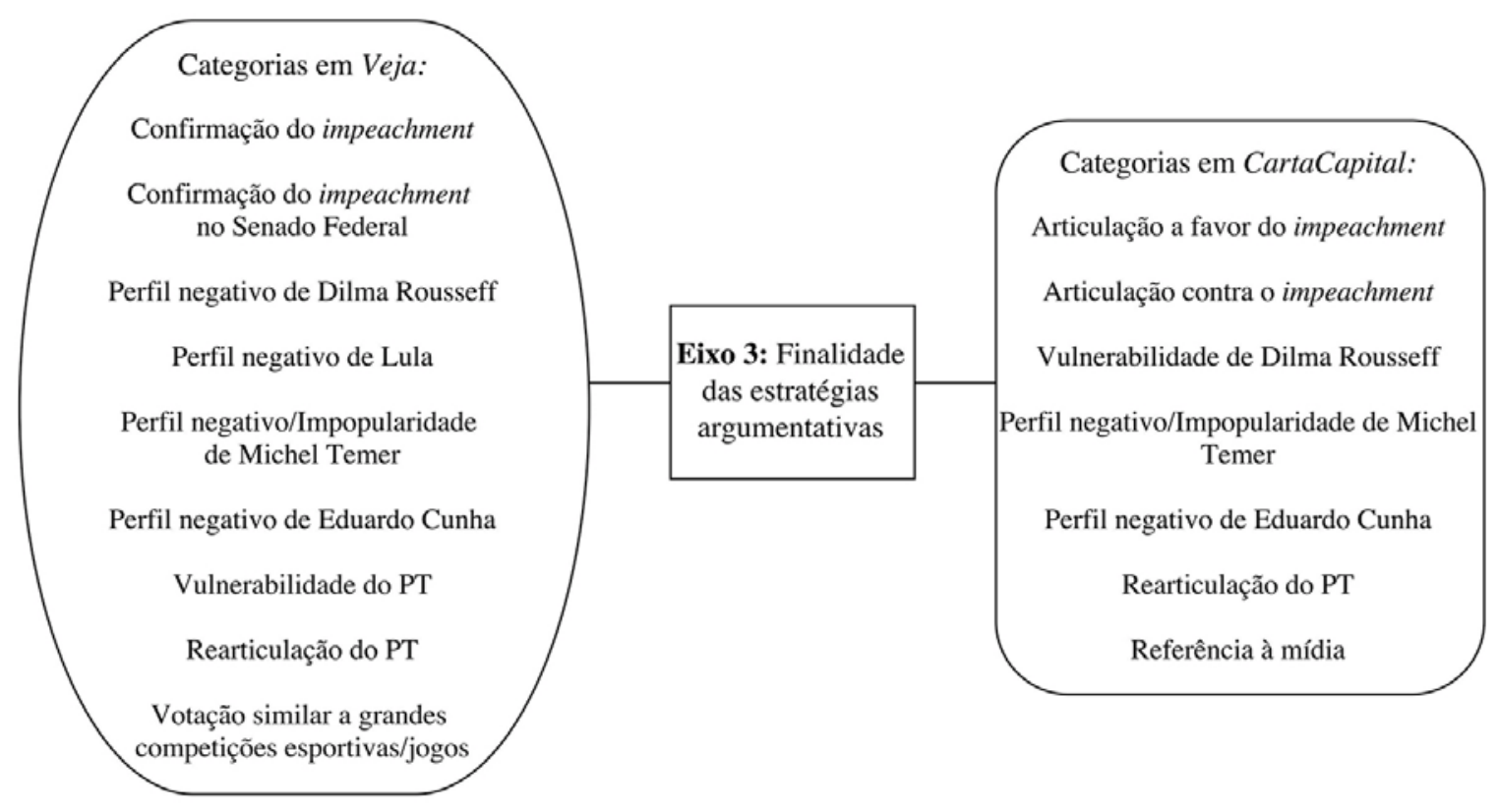

Fonte: Elaborado pelas autoras.

Delineados nossos procedimentos metodológicos, passa-se, agora, à análise. Nos diagramas a seguir, dispomos à esquerda, a análise em Veja e, à direita, em CartaCapital.

Figura 6 - Ator político: Dilma Rousseff. À esquerda, análise em Veja e, à direta, em CartaCapital

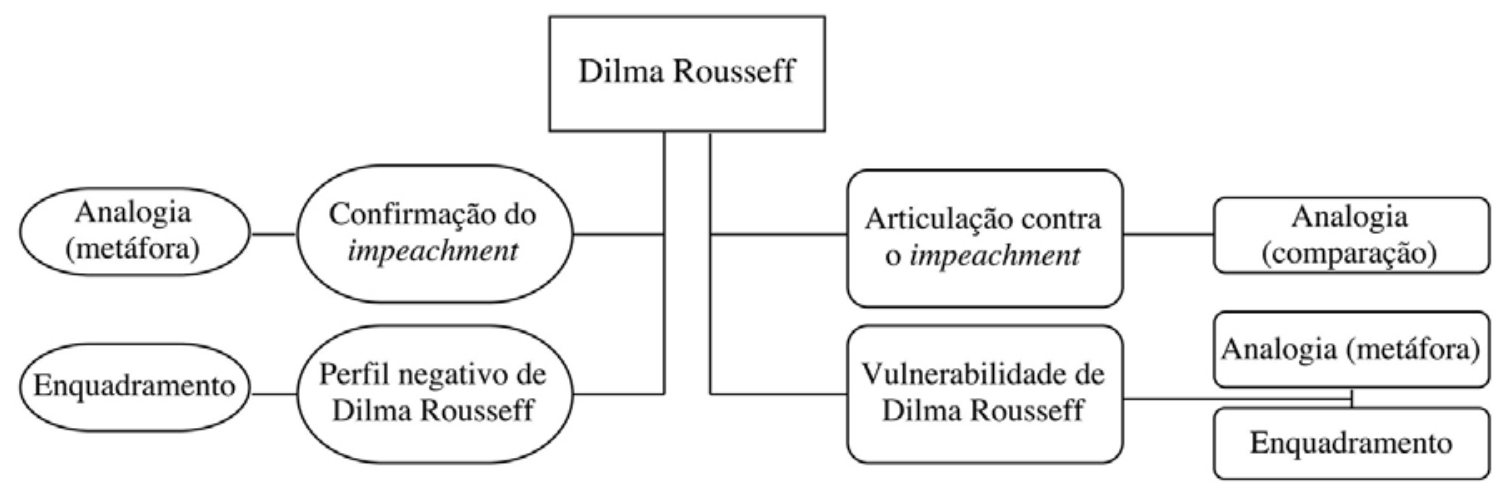

Fonte: Elaborado pelas autoras.

Quando Veja se refere à Dilma Rousseff, apresenta uma "Confirmação do impeachment" por meio de metáforas como "[...] morte política." (JUNIOR et al., 2016, p. 9) e o "[...] Brasil renunciou a Dilma." (p. 11). Além disso, a revista também afirma que os deputados votaram a favor de seu impeachment pela metáfora "conjunto da obra" (p. 11) 
que, segundo a revista, engloba "[...] crime fiscal, recessão econômica e, claro, envolvimento no maior esquema de corrupção já investigado no Brasil." (p. 11). A revista também apresenta um "Perfil negativo" da então presidente. Neste enquadre, junto à Lula, ela teria sucumbido à lei "[...] aos interesses dos poderosos." (p. 10) e se mantido no poder "fraudando eleições, subornando políticos e corrompendo partidos por meio de uma gigantesca estrutura de corrupção [...]" (p. 10-11).

CartaCapital apresenta uma "Articulação contra o impeachment" por parte de Rousseff quando expõe a frase que, a partir do argumento de autoridade, a ex-presidenta proferiu ao ser questionada sobre o empréstimo de aviões que transportava deputados para votarem a favor do seu processo de impedimento: “[...] se houve empréstimo de aviões de empresários para transportar deputados, 'será investigado, divulgado e explicitado. Se houve é lamentável." (revista Carta Capital por BARROCAL, 2016, p. 18).

CartaCapital expõe, ainda, uma "Vulnerabilidade de Dilma Rousseff" em frases que, a partir do argumento de comunidade - aqueles que apelam a valores e crenças, nesse caso, interpelam justiça - Rousseff anuncia "[...] ao mundo seu infortúnio pessoal, o 'golpe de Estado' em curso e 'conspiração' do vice.” (p. 23). Outra frase que expõe sua vulnerabilidade, por meio do argumento de comunidade, é quando a revista expõe frases que a presidente proferiu diante das câmeras: "É estarrecedor que um vice-presidente no exercício do seu mandato conspire contra a presidente, abertamente." (revista Carta Capital por BARROCAL, 2016, p. 23) e "Quando você está sendo objeto de uma injustiça, ou quando você é vítima de um golpe, tem várias operações, mas acho que quem tem honra e dignidade tem uma: resistir." (p. 23). Além do argumento de comunidade, a revista também utiliza o argumento de analogia, por meio da metáfora, para explicitar a vulnerabilidade de Dilma Rousseff: "São poucas as esperanças de livrar a presidente da cassação no Senado após a batalha sangrenta na Câmara." (p. 23).

Figura 7 - Ator político: Lula. À esquerda, análise em Veja e, à direta, em CartaCapital.

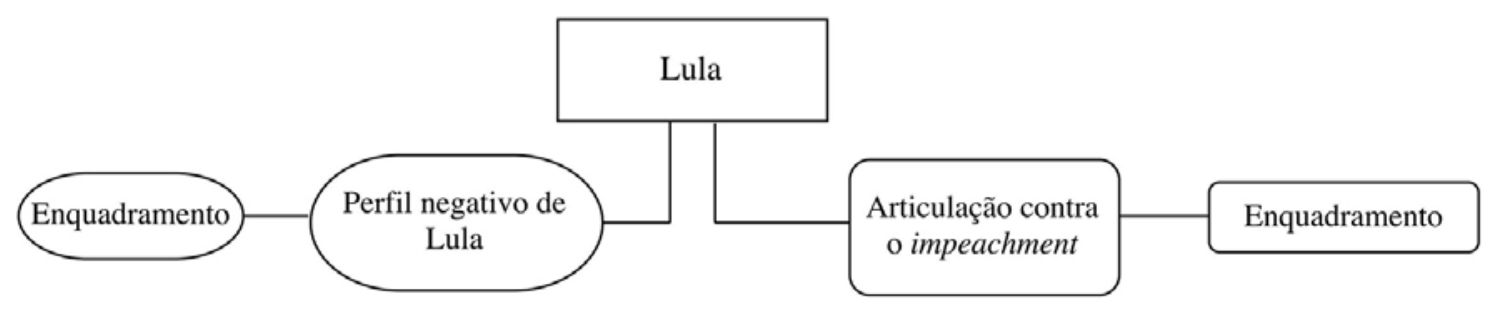

Fonte: Elaborado pelas autoras. 
Veja apresenta um "Perfil negativo" de Lula nas mesmas frases que se refere ao "Perfil negativo de Dilma Rousseff”. Nesse sentido, optamos por não as repetir já que estão no parágrafo acima. CartaCapital apresenta uma "Articulação contra o impeachment" quando cita Lula na frase: "Enquanto negociava com o ex-presidente Lula e o Planalto o voto de seu partido contra o impeachment." (revista Carta Capital por BARROCAL, 2016, p. 20).

Figura 8 - Ator político: Partido dos Trabalhadores (PT). À esquerda, análise em Veja e, à direta, em CartaCapital.

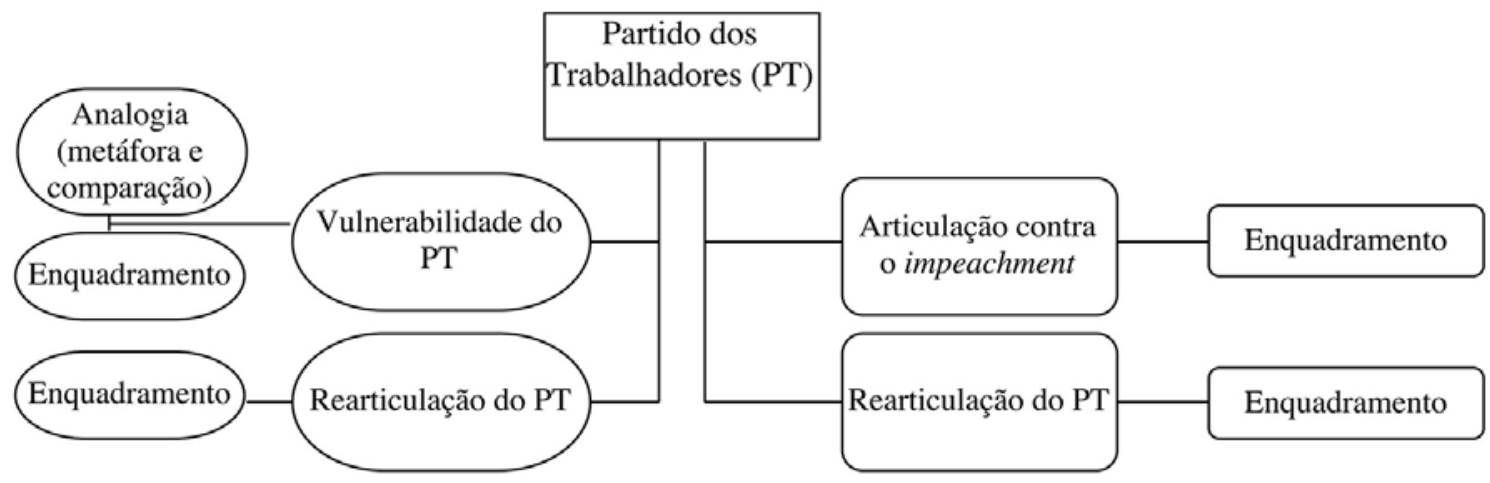

Fonte: Elaborado pelas autoras.

A revista Veja, ao falar sobre o Partido dos Trabalhadores (PT), apresenta, por meio de argumentos de enquadramento, uma "Vulnerabilidade" do partido em frases que dizem que a derrota sofrida por ele é "[...] a maior de sua história." (revista Veja em JUNIOR et al., 2016, p. 12). Veja afirma, ainda, que há uma “[...] desconfiguração ética do partido." (p. 12). Essa mesma "Vulnerabilidade" é exposta também através de metáforas presentes em frases que dizem que as camadas dirigentes foram "[...] capturadas pelo dragão da corrupção partidária e pessoal.” (p. 12) e que o partido “[...] perdeu o rumo quando caiu a máscara de sua própria desvirtude." (p. 12). Além de metáforas, aparece um outro argumento de analogia que é a comparação e que está presente em frases que afirmam que o PT confundiu “[...] nível de renda com classe social, confundiu oprimido com assalariado, confundiu doutrina com dogma, confundiu público com partidário, militante com servidor [...]” (p. 12).

Revista Veja expõe, ainda, uma "Rearticulação" do partido em frases que afirmam, por meio do argumento de enquadramento, que o PT já começou a "[...] articular." (revista Veja por JUNIOR et al., 2016, p. 11) novas eleições presidenciais: "A ideia é que Dilma renuncie para que, em outubro [...] seja convocada uma nova eleição presidencial. É a forma petista de dar o troco a Michel Temer." (p. 11). 
CartaCapital, por sua vez, apresenta, por meio de argumentos de enquadramento, frases que expressam uma "Articulação contra o impeachment" por meio do partido, como: "Explicitar à sociedade a agenda econômica de Temer é uma das últimas esperanças do Planalto e do PT na dificílima tentativa de barrar o impeachment no Senado." (revista Carta Capital por BARROCAL, 2016, p. 21). A revista também evidencia uma "Rearticulação" do partido em frases que, assim como Veja, se referem à convocação de novas eleições presidenciais.

Figura 9 - Ator político: Michel Temer. À esquerda, análise em Veja e, à direta, em CartaCapital

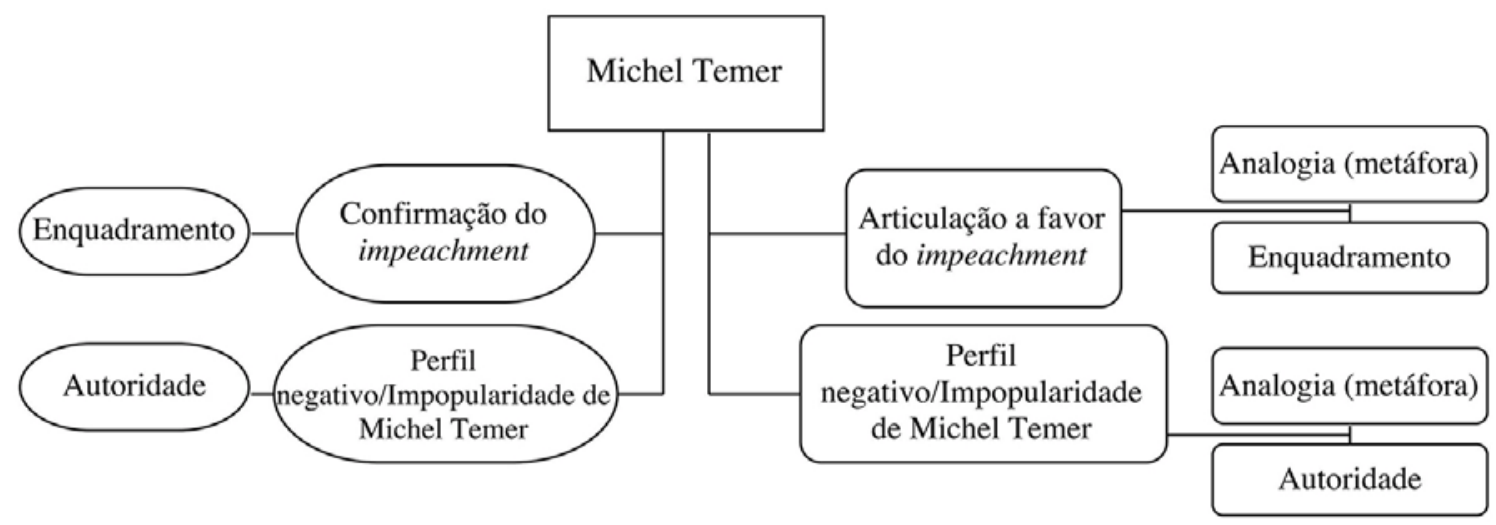

Fonte: Elaborado pelas autoras.

Quando se refere a Michel Temer, Veja, por meio de argumentos de enquadramento, apresenta uma "Confirmação do impeachment": "Uma vitória acachapante da oposição e do vice Michel Temer." (JUNIOR et al., 2016, p. 12). A revista também se usa da autoridade das "pesquisas eleitorais" para falar sobre a impopularidade de Temer: "Ele, que não passa de $2 \%$ nas pesquisas eleitorais e tem $58 \%$ da população contra sua ascensão no poder." (p. 11).

A revista CartaCapital, quando se refere a Michel Temer, expõe uma "Articulação a favor do impeachment" por parte deste. Frases que mostram isso são as que utilizam argumentos de analogia, como a metáfora "golpe" na frase: "Com o apoio empresarial, Temer completa a primeira parte do golpe contra Dilma." (revista Carta Capital por BARROCAL, 2016, p. 18) e a metáfora "[...] pacote de maldades." (p. 18) na frase: "Os tucanos têm planos maquiavélicos para o vice-presidente. Sonham com o esvaziamento de um saco de maldades por parte de Temer [...]" (p. 21). E as que utilizam argumentos de enquadramento em frases: “[...] Temer, beneficiário imediato da queda de Dilma [...]” (p. 18) e "O patrocínio patronal à queda de Dilma Rousseff pode ser só especulação, mas o empresariado está coberto de motivo para desejar Temer na presidência." (p. 20). 
CartaCapital também se refere à "Impopularidade" de Temer em frases contendo metáforas: “[Os tucanos] não querem ser sócios de um governo que, pelo visto, encontraria a impopularidade em cada esquina." (p. 21); e contendo argumentos de autoridade como em frases que a impopularidade de Temer é ressaltada "[...] pelo ministro da Ciência e Tecnologia, Celso Pansera." (p. 21) e pela instituição Datafolha. A revista também mostra um "Perfil negativo" de Temer quando, pela metáfora, refere-se a ele como tendo o "[...] sorriso da Mona Lisa." (p. 18) no título da matéria.

Figura 10 - Ator político: Eduardo Cunha. À esquerda, análise em Veja e, à direta, em CartaCapital

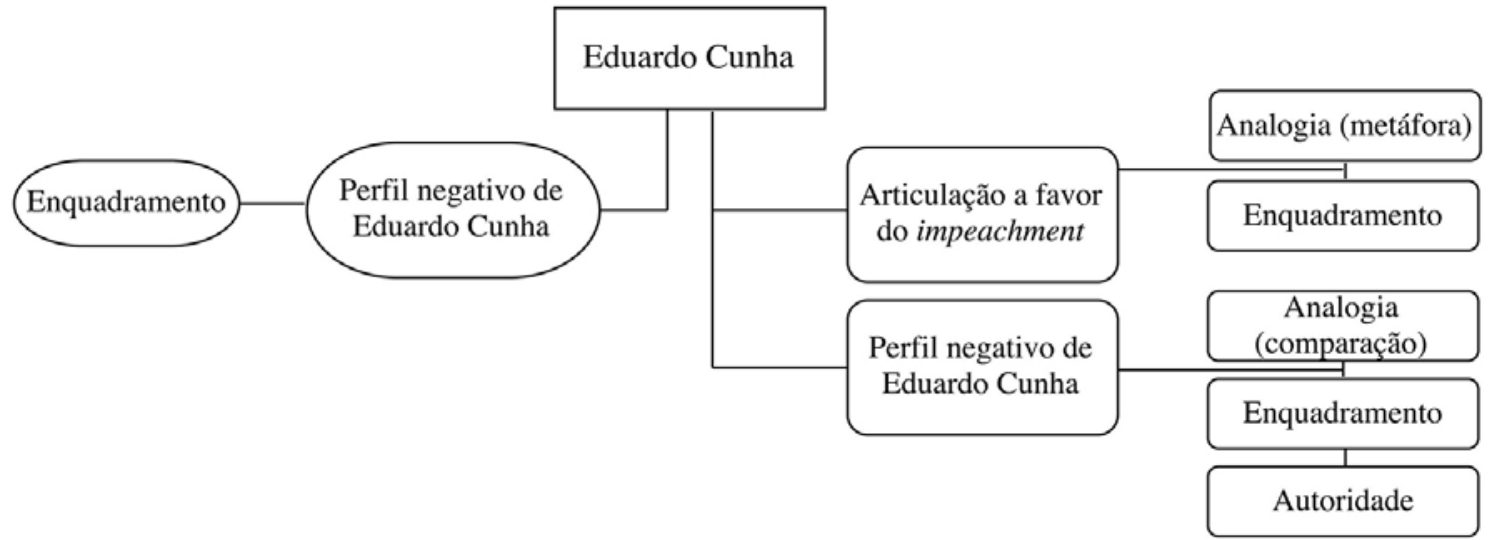

Fonte: Elabora pelas autoras.

Ao se referir a Eduardo Cunha, Veja utiliza adjetivos como "[...] sangue-frio." (JUNIOR et al., p. 11), “[...] corrupto.” (p. 11), “[...] ladrão.” (p. 11) e, ainda, “[...] suspeito no comando.” (p. 13) para expressar, por meio desses argumentos de enquadramento, um "Perfil negativo" do deputado. CartaCapital também expõe esse mesmo "Perfil negativo" através de argumentos de enquadramento como "[...] Cunha tem pressa para essa data [da votação no Senado Federal] chegar. Seria a vingança completa contra Dilma." (revista Carta Capital por BARROCAL, 2016, p. 22); de autoridade, quando introduz a fala do senador João Capiberibe: "A convivência entre Cunha e Temer será muito difícil, o Temer vai querer resistir ao Cunha, mas é só um instrumento dele, o grande maestro do impeachment é o Cunha." (p. 23) e, também, de analogia, por uma comparação na frase: "O senador [Renan Calheiros] anunciou que se portaria com 'absoluta isenção e total neutralidade', sem atropelos, um contraste em relação à postura de Cunha." (p. 22).

Outra categorização da finalidade da estratégia argumentativa que aparece na matéria analisada em CartaCapital é a "Articulação a favor do impeachment" por parte de 
Eduardo Cunha. Para isto, a revista utiliza argumentos de enquadramento quando diz que: “[...] Paulinho da Força, da tropa de choque de Cunha, diz [...] tem muita gente querendo financiar esse negócio de impeachment." (revista Carta Capital por BARROCAL, 2016, p. 18); e de analogia, também por comparação na frase: “[...] Calheiros promete não ser tão afoito quanto o colega Cunha." (p. 19)

Figura 11 - Ator político: Impeachment. À esquerda, análise em Veja e, à direta, em CartaCapital

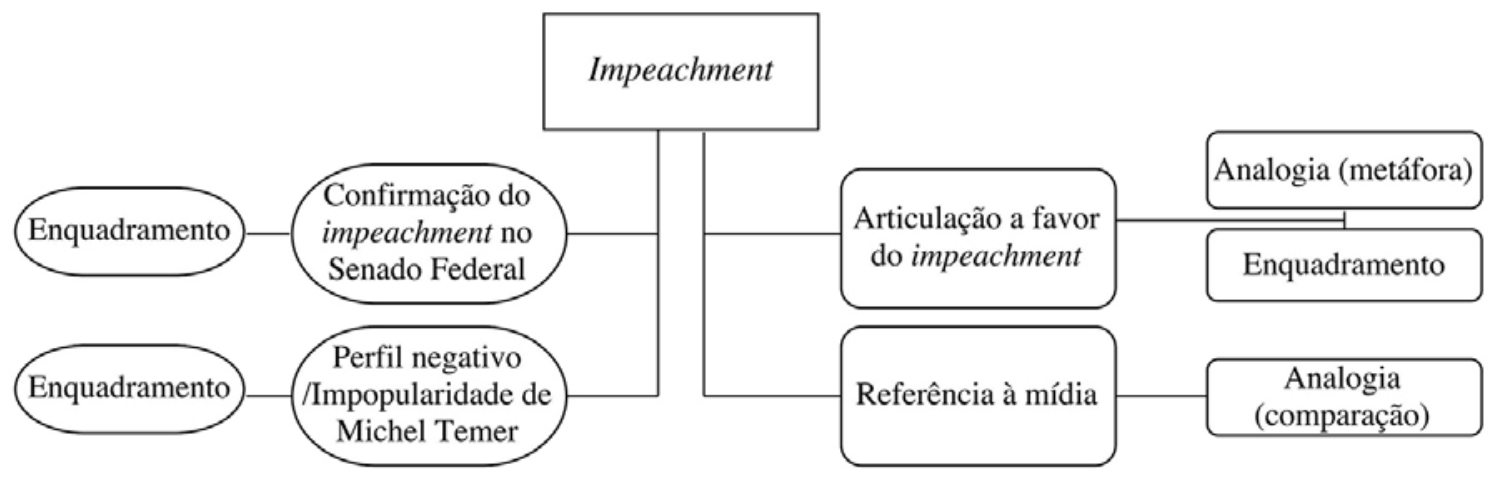

Fonte: Elaborado pelas autoras

Ao falar sobre o próprio processo de Impeachment, Veja apresenta, por meio de argumentos de enquadramento, uma confirmação do processo também no Senado Federal. A revista afirma que: "O afastamento é considerado barbada. Já há folga da maioria na casa." (revista Veja por JUNIOR et al., 2016, p. 12) e que "Se não houve uma reviravolta, o Senado seguirá a Câmara e formalizará a percepção de que o governo Dilma acabou faz tempo." (p. 12). Revista Veja, também por meio de argumentos de enquadramento, apresenta a votação na Câmara dos Deputados com uma cobertura similar a como os veículos midiáticos se referem a grandes eventos e competições esportivas. Por meio de frases como: "[...] a multidão acompanhou a votação em três telões instalados na orla do Rio de Janeiro." (p. 10); "[...] os deputados começaram a cantar: 'Eu sou brasileiro, com muito orgulho, com muito amor."' (p. 9) e "Pelas ruas das principais capitais brasileiras, ouviram-se fogos de artifício e buzinaços." (p. 10). Podemos ver que a revista enquadra a votação da mesma forma que um jogo de futebol de Copa do Mundo, por exemplo. 0 fato de a revista tratar como "[...] placar." (p. 10) a votação e, no título, usar a palavra "[...] folga." (p. 8) também corrobora essa percepção.

Por fim, CartaCapital, quando se refere ao Impeachment, apresenta duas categorizações: mostra uma "Articulação a favor do impeachment" por meio do argumento 
de analogia por comparação ao expor que no dia da votação na Câmara dos Deputados “[...] o aeroporto internacional recebeu três vezes mais jatos particulares do que o habitual [...]" (revista Carta Capital por BARROCAL, 2016, p. 18); e de argumentos de enquadramento na frase: “[...] para descobrir se a cassação presidencial foi comprada." (p. 18). A revista também apresenta uma "Referência à mídia" quando escreve, por meio do argumento de analogia por comparação, que: “[...] Enquanto a mídia brasileira legitima o golpe, a mídia estrangeira define os fatos como eles são. Basta ver as reportagens e editoriais em publicações como The New York Times, Der Spiegel, Guardian, Le Monde e até a liberal The Economist." (p. 23).

\section{Conclusão}

Este trabalho se propôs a analisar duas matérias de caráter jornalístico em duas das maiores revistas em circulação no território brasileiro: Veja e CartaCapital. Dessa forma, nosso corpus foi constituído pela matéria "Folga de 25 votos", de Veja, e "O sorriso da Mona Lisa", de CartaCapital.

A partir desta análise, podemos concluir que ao falar de Dilma Rousseff, as revistas apresentam pontos de vistas diferentes. Enquanto Veja decreta a "[...] morte política." (VEJA, 2017, p. 9), demonstrando uma confirmação do impeachment; CartaCapital apresenta Dilma Rousseff em articulação contra o processo. Ainda, enquanto Veja mostra um perfil negativo da ex-presidente, CartaCapital expõe sua vulnerabilidade e apelo aos valores de justiça.

Ao se referirem à Lula, Veja expõe um perfil negativo do ex-presidente, enquanto CartaCapital disserta sobre sua articulação para barrar o processo. Quando as revistas se referem ao Partido dos Trabalhadores (PT), ambas focam na rearticulação do partido por meio de pedido de novas eleições presidenciais, todavia, diferem quando Veja mostra a "[...] desconfiguração ética do partido." (revista Veja por JUNIOR et al., 2016, p. 12) e CartaCapital mostra a articulação contra o processo de impeachment.

Quando falam sobre Michel Temer, ambas revistas expõem sua impopularidade por meio de pesquisas eleitorais e de instituições como o Datafolha. Porém, diferem quanto ao processo de impeachment. Em Veja, vemos que quando se referem a Temer, falam que a votação na Câmara dos Deputados foi uma "[...] vitória acachapante." (Veja por JUNIOR et al., 2016, p. 10) para o mesmo; já CartaCapital mostra a articulação de Michel Temer a favor do processo de impeachment dizendo que o então vice-presidente completou a primeira parte 
do "[...] golpe." (Carta Capital por BARROCAL, 2016, p. 18). Em relação a Eduardo Cunha, ambas revistas, novamente, convergem ao exporem seu perfil negativo. No entanto, CartaCapital também expõe a articulação do deputado a favor do impedimento de Dilma Rousseff.

Por fim, em relação ao próprio processo de impeachment, a revista Veja aposta na confirmação do processo também no Senado Federal e enquadra a votação na Câmara dos Deputados de modo similar a jogos esportivos e grandes competições. CartaCapital, no entanto, demonstra uma articulação a favor do impeachment ao afirmar que no dia da votação houve "[...] três vezes mais jatos particulares do que o habitual." (Carta Capital por BARROCAL, 2016, p. 18) e também compara a cobertura da mídia internacional com a local dizendo que a última “[...] legitima o golpe." (p. 23), enquanto a primeira mostra “[...] os fatos como eles são." (p. 23).

Vemos, então, que as revistas convergem quando falam sobre os atores políticos Michel Temer e Eduardo Cunha, contudo, alguns pontos são divergentes. CartaCapital, por exemplo, refere-se ao processo de impeachment como golpe e expõe a vulnerabilidade de Dilma Rousseff, enquanto Veja decreta a confirmação do processo expondo um perfil negativo de Rousseff.

Deste modo, podemos observar que as metáforas "morte política", em Veja, e "golpe", em CartaCapital, por exemplo, apresentam uma vulgarização da informação que interpela o "fazer sentir" da dramatização exposta por Charaudeau (2015). Essa dramatização é exposta, pelo autor, como o ato que tem, por plano de fundo, o desencadeamento de "paixões", da afetividade e subjetividade do leitor. A dramatização também pode ser observada por meio do conceito de amálgama - aquele que se refere aos valores em sociedade - quando CartaCapital expõe Dilma Rousseff interpelando valores de justiça.

O conceito de psicologização, também de Charaudeau (2015), é exposto quando, ao falar do perfil negativo de Dilma Rousseff e de Lula, bem como da vulnerabilidade do PT, a revista Veja expõe uma culpabilização desses três atores dizendo que eles fraudaram eleições, subornaram políticos e corromperam partidos "[...] por meio de uma gigantesca estrutura de corrupção montada dentro do aparelho estatal." (Veja por JUNIOR et al., 2016, p. 11). Outro efeito da psicologização é que, além da culpabilização, ela atua criando grupos de "inimigos", frios e calculistas, uma espécie de "todo poderoso" que faz vítimas, o que colabora, muitas vezes, com a exposição desses mesmos três atores pela revista Veja e com a exposição de Michel Temer e Eduardo Cunha por CartaCapital. 


\section{Referências}

BARROCAL, André. 0 sorriso da Mona Lisa. CartaCapital, São Paulo, v. 22, n. 989, 27 abr. 2016.

BOURDIEU, Pierre. A economia das trocas linguísticas. 2. ed. São Paulo: EDUSP, 1998.

BOURDIEU, Pierre. Economia das trocas linguísticas. In: ORTIZ, Renato (Org.). Pierre Bourdieu: sociologia. São Paulo: Ática, 1994, p. 156-183.

BOURDIEU, Pierre. 0 poder simbólico. 16. ed. Rio de Janeiro: Bertrand Brasil, 2012.

BRETON, Philippe. A argumentação na comunicação. Bauru: EDUSC, 1999.

BRETON, Philippe. Com convencer? Da comunicação argumentativa à manipulação. Revista Eletrônica de Estudos Integrados em Discurso e Argumentação, Ilhéus, n. 3, p. 117-132, 2012.

CARTA CAPITAL. São Paulo, v. 22, n. 989, 27 abr. 2016.

CHARAUDEAU, Patrick. A conquista da opinião pública: como o discurso manipula as escolhas políticas. São Paulo: Contexto, 2016.

CHARAUDEAU, Patrick. Discurso das mídias. São Paulo: Contexto, 2015.

FOUCAULT, Michel. A ordem do discurso. São Paulo: Edições Loyola, 1999.

JUNIOR, Policarpo et al. Folga de 25 votos. Veja, São Paulo, v. 49, n. 2474, 21 abr. 2017. Edição extra.

STOPPINO, Mario. Poder. In: BOBBIO, Norberto; MATTEUCCI, Nicola; PASQUINO,

Gianfranco. Dicionário de política. 11. ed. Brasília: Editora Universidade de Brasília, 1998.

VEJA. São Paulo, v. 49, n. 2474, 21 abr. 2017. Edição extra. 


\title{
Dilma Rousseff's impeachment: analysis of the argumentative strategies of Veja e CartaCapital after the voting at the Lower House
}

\begin{abstract}
This work analyzes the articles "Folga de 25 votos" by Veja magazine and "Sorriso da Mona Lisa" by CartaCapital magazine, both articles refer to the impeachment process of Dilma Rousseff in the Lower House. Therefore, we are supported by authors such as Foucault, Bourdieu and Charaudeau who discuss discourse and power relations in society. For an approximation with our objects, we are mainly based on Charaudeau that talks about the discourse of the media. The methodology is based on the four argumentative strategies presented by Breton: authority, framework, community and analogy. As a conclusion we observe that the magazines converge when they expose a negative profile of Eduardo Cunha and unpopularity of Michel Temer, however, they differ when they mention other participants of the process such as Dilma Rousseff and Lula.
\end{abstract}

\section{Keywords}

Media discourse. Dilma Rousseff's impeachment. Veja. CartaCapital. 